\title{
Research Projects in Science Education for Preschool, Evolution, and Results in Curriculum Development, Evaluation Tools, and Teacher Workshops.
}

\author{
Diana López-Tavares and Mario Ramírez-Díaz \\ Instituto Politécnico Nacional, Calz Legaria 694, Mexico City, Mexico 11500 \\ Soraida Zúñiga-Martínez \\ Universidad Autónoma de San Luis Potosí, Niño Artillero 150, San Luis Potosí, S.L.P. 78290
}

\begin{abstract}
The national preschool curriculum in Mexico considers 80 hours for learning science during the school year. Early child science education is essential for developing skills and positive attitudes toward science. However, for the instruction to be successful, teachers must have adequate knowledge of science and science didactic. In the case of Mexico, preschool science curriculum and teacher preparation are insufficient. There are few professional development courses for in-service and pre-service teachers, and the material and textbooks for this educational level is limited. The Department of Physics Education of the National Polytechnic Institute (IPN) in Mexico had different projects that involve the design of curriculum, experiment manuals, evaluation tools, postgrad thesis, and teacher professional development workshops. This work presents the results and analysis of the evolution of these projects and their influence in classrooms.
\end{abstract}




\section{INTRODUCTION}

In Mexico, the National Education model implemented in 2017 by the Secretary of Public Education (SEP for the acronym in Spanish) sets 80 hours in the scholar year for the subject "Exploration of the natural and social world" for the preschool level. The learning goal of the subject is promote the development of scientific knowledge and skills in children, to experiment with materials, test their assumptions, observe and communicate their findings [1].

SEP makes free textbooks available to teachers with activities and experiments to address some science topics [2]. But most of the teachers at this level use demonstration experiments. For these experiments, teachers indicate to the students what will be done; they ask students to explain what they think will happen. After that, teachers do the experiment in front of the students. Finally, teachers give the students some vague explanations of what happened.

In surveys answered for over 100 preschool teachers about what kind of experiments they do in science activities, the answers were the same: the volcano with baking soda and lemon, sprouting a bean, moving a metal can with a charged balloon, make slime, among others. Taking the specific case of the experiment of moving metal can with a charged balloon, in the surveys was found that preschool teachers explain to the students that the phenomenon is related to charges and energy, but the truth is that they do not understand how it works. So, most science classes in preschool are for showing something eye-catching and novel to students, where communication of ideas and observation is limited, and there is no complete inquiry process.

The training of preschool teachers, both pre-service and in-service, is provided by the SEP in most of the cases. The coverage of the professional development programs is insufficient, and they are about theories and methodologies about how to teach science that rarely is used in practice, and they do not include teacher preparation in scientific knowledge [3].

In 2012 a preschool teacher approached the Physics Education Research group of the National Polytechnic Institute (IPN for the acronym in Spanish of Instituto Politécnico Nacional) [4] to collaborate in finding a solution and address the problems of since education in preschool level. From that date until now, four postgraduate theses have been developed at the IPN, a project funded by the National Council of Science and Technology of Mexico (CONACYT for the acronym in Spanish of Consejo Nacional de Ciencia y Tecnología) and the proposal of a teacher training program with the collaboration of three universities and a state technology department. A total of six projects have been developed by the IPN to investigate and support science education at the preschool level. In this paper is presented a synthesis of the results and evolution of these projects. Named as Project-1 to Project- 6 in Table 1 and ordered by temporality, they will be described in detail in the following chapters.
For better organization, this paper will describe the components of each project in parallel, dividing them into three groups:

1. Topics in Physics and teaching methodology

2. Assessment tools

3. Teacher professional development

TABLE 1: Preschool projects developed by the IPN Physics Education Research group

\begin{tabular}{|c|c|c|c|}
\hline \# & $\begin{array}{l}\text { Topics in Physics } \\
\text { and teaching } \\
\text { methodology }\end{array}$ & $\begin{array}{c}\text { Assessment } \\
\text { tools }\end{array}$ & $\begin{array}{c}\text { Teacher } \\
\text { professional } \\
\text { development }\end{array}$ \\
\hline 1 & $\begin{array}{l}\text { Electricity using } \\
\text { Inquiry Learning }\end{array}$ & Rubrics & $\begin{array}{c}\text { Two } \\
\text { workshops }\end{array}$ \\
\hline 2 & $\begin{array}{l}\text { Motion, magnetism, } \\
\text { and sound using } \\
\text { Gamification }\end{array}$ & $\begin{array}{c}\text { Diagnostic } \\
\text { questionnaire, } \\
\text { Rubrics } \\
\text { Checklists }\end{array}$ & \\
\hline 3 & $\begin{array}{l}\text { Motion, sound, } \\
\text { magnetism using } \\
\text { Corners of Physics }\end{array}$ & $\begin{array}{c}\text { Diagnostic } \\
\text { questionnaire } \\
\text { Rubrics } \\
\text { Checklists }\end{array}$ & \\
\hline 4 & $\begin{array}{l}\text { Motion, magnetism, } \\
\text { and light using } \\
\text { Inquiry Learning }\end{array}$ & Rubrics & $\begin{array}{c}\text { Four sessions } \\
\text { workshop }\end{array}$ \\
\hline 5 & $\begin{array}{l}\text { Light and electricity } \\
\text { using Inquiry } \\
\text { Learning }\end{array}$ & & $\begin{array}{c}\text { Five } \\
\text { workshops }\end{array}$ \\
\hline 6 & $\begin{array}{l}\text { Light using Inquiry } \\
\text { Learning }\end{array}$ & $\begin{array}{c}\text { Rubrics } \\
\text { Checklists } \\
\end{array}$ & $\begin{array}{l}\text { One online } \\
\text { workshop }\end{array}$ \\
\hline
\end{tabular}

\section{TOPICS IN PHYSICS AND TEACHING METHODOLOGY}

The master's program in Physics Education of the IPN was created in 2006. One of its goals is "To know the conditions of teaching and learning Physics, in order to use this knowledge to improve the educational processes" [4]. The research carried out in the program is mainly for high school and university levels in Mexico. In 2012, the first preschool candidate entered the postgraduate level, opening the opportunity to initiate research in science learning in preschool. Project-1 developed by the preschool teacher as part of her master's thesis [5] includes the research question What physics topics can be implemented with preschool students to develop the SEP's learning goals?

Previous works of physics education in preschool $[6,7]$ suggest that topics like electricity, sound, and motion are ideal to be worked with kids and engage them in scientific activities. For Project-1, instructional design for learning electricity using an adaption of an inquiry cycle was developed [5]. The learning cycle included moments for observing, exploring, asking questions, hypothesizing, experimenting, recording data, testing hypotheses, and communicating the results. The students in teams interacted with electric circuits created with Play-Doh and LEDs. They 
play with the material in order to find the necessary conditions to turn on LEDs in different configurations, and they described their findings with drawings and explanations.

For Project-2, over100 preschool teachers participated in a survey to identify the physics topics that they would like to work with their students. The teachers selected: motion, light, electricity, magnetism, and sound. Movement, magnetism, and sound were the topics selected to be developed in Project-2, using the gamification methodology. Different toys were used in this project for the activities with the kids, like cars, bells, balls whistles, xylophones, magnets, and others. A book for teachers that include the curriculum for those topics and electricity from Project-1 is on revision for publishing. The book includes everyday language and explanation of the physics content. It includes the planning document requested by the SEP and the description of didactic situations based on inquiry learning and gamification.

For Project-3, a successful didactic strategy called the Reading Corner [8], where various books are placed in the corner of the classroom for children to sit and read books, was modified to make a "Science Corner. " In this strategy, toys were placed for the students to settle and explore the toys. In the strategy, the students are organized in teams. The teacher assigned a challenge to each team and give them a specific time to visit the Science Corner and solve the challenge [9]. The challenges can be, for example, to discover how to move the different car toys or differentiate the sound produced by the xylophone and play a song.

Projects-1 to 3 provides different experiences for the students with three methodologies (Inquiry Learning, Gamification, and Science corners). These experiences help to the research group to select Inquiry Learning as the methodology to continue working in the following projects since it is a methodology well known for teachers, and it is the one promoted by SEP documents.

The rest of the projects continued with the improvement of the themes of motion, magnetism, and light. Other topics in physics, such as properties of matter (e.g., density, weight, and states of matter) and astronomy, have been proposed by teachers and researchers and are being considered.

\section{ASSESSMENT TOOLS}

For Project-1, a checklist was created to evaluate the students' knowledge using five items (for example: know the vocabulary related to science) and a rubric to evaluate the criteria of knowledge, asking questions and recording/organizing information with four levels of achievement. These tools were improved in Project-2. The project also includes the proposal of using science activities not only for the impact in the learning goals in the subject of exploration of the science and social world, but also the activities could help foster the development of other preschool standards, such as communication, socialemotional development, and Mathematical Thinking.

Project-2, called "Evaluation of the different field standards at the preschool level through the development of science skills and attitudes," was funded by the CONACYT. In this project, a series of instruments were developed to assess students' skills and attitudes. For this, three different instruments were designed and implemented:

1. a questionnaire to evaluate children's prior knowledge;

2. rubrics to evaluate the development of science skills;

3. rubrics to evaluate conceptual knowledge on the subject of electricity.

The rubrics considered four levels of achievement: apprentice, novice, expert, and master.

The validation of the evaluation tools was by a revision of a group of experts that includes PhDs in Physics, Math Education, Science Philosophy, Physics Educations, and preschool teachers with a master's degree in Physics Education.

The instruments were implemented during the replication of the Project-1 teaching proposal. Nineteen students between the ages of 5 and 6 years old participate in the implementation. Before, during, and after the implementation, the student narrative was analyzed using checklists and rubrics to assess student knowledge and achievement.

The results showed that the majority of the students achieved a master's level in the development of skills and basic knowledge of electricity. In a comparison of the diagnostic results of previous knowledge and the student's narrative after the activities, significant progress was observed in topics such as what electricity is. After the intervention, the students were able [10]:

1. To establish a cause-effect relationship in electricity phenomenon;

2. To express themselves orally with greater security;

3. To generate questions

4. To make use of a more formal vocabulary, using terms such as electricity, electric charge, hypotheses, and others;

5. To stay longer in the didactic activities;

6. When they classify, they do it based on what they observed;

7. When they were questioned, they argue easily.

Besides, the children expressed interest in learning more about the subject and shared their experiences with their parents and families. That students share their knowledge outside the classroom was an important indicator of the success of the activity for parents and teachers.

Project-3 used the evaluation tools developed in Project-2, making the appropriate modifications to adapt them to the topics addressed in that project. The results showed student conceptual learning for motion, sound and magnetism, and the development of communication skills.

In Projects-4 and 6, workshops were designed to share with teachers the teaching material, methodologies, and 
evaluation tools. After the workshops, teachers were invited to design a science activity for working with their students in their classes. Rubrics were used to evaluate the impact of the workshop content in the teachers' activities design. The results showed that teachers included elements of physics addressed in the workshop and better implementation of inquiry activities, considering ideas from the students and moments of exploration, discussions, and collaboration.

The training actions also require to be evaluated by the assistants to ensure their effectiveness and help to improve them. A questionnaire with a Likert scale to evaluate the content, curriculum standards, the strategies used in the workshop, organization, and mastery of the exhibitors was designed and answered by the participants. All the evaluation tools can be found on the IPN website [11].

\section{TEACHER PROFESSIONAL DEVELOPMENT}

As described in the introduction, the primary motivation of the projects was to improve the way of approaching scientific activities in preschool classrooms. After the development of curriculum and evaluation tools, contact with teachers was necessary for sharing the findings of the projects. Project-1 included two teaching workshops carried out by the IPN graduate student (who is also a preschool teacher). These workshops lasted three hours each, and approximately 30 teachers participated in each one. The workshop presented how to address the topic of electricity using the strategies developed in Project-1 and its evaluation tools. The workshop was well received by preschool teachers, the maximum enrollment quota was covered in a few hours and it was evaluated by the participants as excellent using an evaluation questionnaire at the end of the workshop. Participants reflected on how physics helps develop skills and abilities associated with mathematical vocabulary, scientific thinking, and arts. In this workshop, it was found that preschool teachers handle the principles of inquiry well, and they are very interested in learning more about science to improve the experiences of their students. The experience of those workshops suggested that the workshops should be focused on teachers learning more science and putting their knowledge of inquiry learning into proper practice.

For the following teaching workshop, Project-4, a sample of 50 preschool teachers (from public and private institutions) was interviewed to explore more their experiences in science activities in their classrooms [3]. The results show that teachers feel insecure in the implementation of science activities because they do not know what to teach to the kids and how. They know what Inquiry learning is and its characteristics, but they do not know how to put it into practice. Therefore, they do not plan significant learning situations nor generate a learning environment that supports the development of skills and motivate children.
An essential difference between the first workshops (Project-1) and the following ones (project-4 and 5) is that in Project-1, the workshop participants developed the activities that were intended for children, with the aim of that the participants knew and understood them. Instead, in the workshops in Project-4 and 5, the activities were planned for the teachers' learning. Although the activities designed for children and the workshop were related, the workshop activities were not designed for teachers to replicate in their classrooms. The goal was that teachers were able to design activities for their students, using parts of the workshop experiences or not, but improve the implementation of science activities in the classroom.

The design and development of the workshops of Project-4 and 5 were mainly in charge of Physicists and Researchers in Physics Education with permanent communication with preschool teachers. The project participants who are preschool teachers did not feel secure about being in charge of the workshops at the time that the workshops were held. Great wealth was found in the communication that took place in the Project-1 workshop where the facilitator was also a preschool teacher. So, more research is planned to explore the benefits of having a workshop's faciliatory that is a preschool teachers, compared with an expert researcher in physics education.

The design of the teaching workshops was based on two firsts: 1) "Use physics as a means to an end, not an end in itself." It is not enough for preschool teachers to carry out experiments or scientific experiences within the classroom. It is also necessary that teachers understand the basic principles of physics in order to achieve the learning goals set by preschool programs. 2) "The preschool teachers must know physics at the level they teach," which implies that physicists and preschool teachers must be able to bring physics to the level of a preschool student. It is not necessary that the scientific knowledge of the teacher of preschoolers are as formal and coarse as experts, only enough to address the topics at the level at which they work.

Project-4 took place in Mexico City. The workshop lasted four monthly sessions and in it participate six teachers. The workshop used parallel instruction, where the participants experience activities as students but reflect about them from their teaching experiences and practice. The workshop addressed physics principles of motion, magnetism, and light, where teachers experiment in an inquiry learning process. The creation of an assessment instrument to evaluate conceptual learning and skills development and attitudes was also included as part of the activities of the workshop. As a result of this intervention, the teachers stated that the basic physics course was an essential element since it served as a basis for them to modify their planning, evaluations, and learning environments. Participants made changes in their planning, included collaborative work, critical and reflective thinking, and practices of oral and written communication. 
In Project-5, a series of workshops called "Sciences, Mathematics and Communication for children" was held in the same place that workshops of Project-1. A large number of the participants in the Project-1 workshop participated again in the Project-5. The sessions were quickly filled.

In addition to having objectives similar to the other workshops, learn science and experience inquiry learning, it was also intended to show how science activities help develop other skills such as communication and mathematical thinking. So, this workshop included data collection and recording activities and more time to communicate and share ideas. The design of the project-5 workshops was completed with ideas from the physics curriculum through experience [12].

This workshop was conducted three times, with a total of 78 participants. At the end of the workshop, teachers were invited to design science activities for their students and send evidence of the implementation. 7 participants (9\%) did it. The hypothesis behind the low percentage participants that implement in classroom is that teachers need more accompaniment, for example more workshops as a space for teachers to share what have been the troubles faced to implement, and how to make them feel more supported. Most of the comments that teachers share in the evaluation questionnaire at the end of the workshops ask for a continuation of the workshop, for example the next teacher answer:

"I would like a continuity course to be offered ... so that it gives us the opportunity that when applying in our class what we have just seen, we can express doubts or concerns so as to have the opportunity to receive suggestions that we can follow in good time."

A teacher professional program that involve meetings and workshops often during the scholar year to continue with the research about teachers' science and teaching ideas, and support of the classroom implementation is being planned to be implemented after the COVID19 crisis.

As a result of this attempts, a teacher 's guidebook in under edition. The book describes how to implement inquiry activities in preschool, includes the activities, experiments and physics, the class lesson according with the SEP format, and evaluation tools.

Lastly, Project-6 takes elements from the face-to-face workshops to create an online mini-course for teachers. A Moodle course with four modules was created to be attended one module per week. Eight teachers from a preschool participated.

The course explores new components, including reviewing readings on science education for children, the use of interactive simulations and virtual games to address physics topics, and analysis and reflection of videos showing the implementation of experimental activities in preschool classrooms using inquiry learning strategies.

This project is the thesis topic of a graduate student at the IPN and it is in the data analysis phase. The preliminary results show an improvement in the teachers' understanding of the physics content addressed in the workshop (light). Also, the virtual workshop has a positive impact on the planning of the teachers' activities to develop with their students, incorporating elements observed in the implementation videos and also integrating the use of technological tools (simulations and virtual games).

\section{CONCLUSIONS}

In this article, six projects for science learning at the preschool level developed by the Physics Education research group of the IPN in Mexico were presented. The projects were divided into three components:

1. Topics in Physics and teaching methodology: the themes of electricity, motion, magnetism, sound, and light have been developed. The methodologies of Inquiry Learning, Gamification, and Corners were implemented in the classroom, and their impact was evaluated. Inquiry Learning is the one that has been best adapted to the context of preschoolers, and teachers know best. The aim is to enlarge the curriculum developed at the moment with astronomy and properties of matter activities.

2. Evaluation tools: Several evaluation tools as diagnostic questionnaires, checklists, and rubrics, have been developed to evaluate students' conceptual learning and skills for the implementation of science activities in preschools classrooms. Other tools also have been designed and implemented to evaluate the impact of teacher training workshops in the instructional design of science classes of the teachers that participate in the workshops.

3. Teacher professional development: workshops have been implemented and well received by the community of preschool teachers. Participating teachers have already implemented strategies in their classrooms as a result of the workshops. These workshops have been mostly single session. A training program that consists of several sessions is being designed, where the topics of physics developed by the research group are addressed, both face-to-face and virtually.

The last two projects are still in process, and there is still data to analyze. In general, it shows a positive impact on science education in preschool, in student learning, and supporting teachers to improve their practice.

[1] Secretaria de Educación Pública de Mexico. Planes y Programas de Estudio para Preescolar. In https://www.planyprogramasdestudio.sep.gob.mx/descarg

ables/biblioteca/preescolar/1LpM-PreescolarDIGITAL.pdf (2017) 
[2] Secretaria de Educación Pública de Mexico. Cátalogo Dígital de Libros de Texto Gratuitos. In https://libros.conaliteg.gob.mx/catalogo.htm?g=4\&a=1

[3] M. Franco-Martínez. Uso de la Física como estrategia de formación para maestros de preescolar en el campo formativo conocimiento del mundo natural. Master Thesis in Physics Education. IPN, México, (2019).

[4] Instituto Politécnico Nacional, Posgrado en Física Educativa, in https://www.cicata.ipn.mx/ofertaeducativa/fisica-educativa/posgrados/maestria.html.

[5] G. Nieto. Estrategia metodológica para desarrollar la habilidad de observación en el campo formativo exploración y conocimiento del mundo en la educación preescolar. Master Thesis in Physics Education. IPN, México, (2015).

[6] C. Starci. Close cooperation of Primary, Secondary, and University professors to teach distance force concepts in primary school. The World Conference on Physics Education. Bahcesehir University, Turkey (2012).

[7] S. Mohd and S. Sheikh. Using action research to improve the teaching of electricity for primary science physics. The World Conference on Physics Education, Bahcesehir. University, Turkey (2012).

[8] A. Pedrero. Metodología de Rincones Tradición e innovación en educación infantil (3-6 años). Editorial de la Infancia, España. (2012).

[9] R. Franco-Martínez. Implementación de Rincones de Física para el desarrollo de habilidades de pensamiento en niños preescolares. Master Thesis in Physics Education, IPN, México, (2019).

[10] M. Ramírez. Physics for skills development in preschool in Mexico. Journal of Physics: Conf. Series 1287 (2019). doi:10.1088/1742-6596/1287/1/012019

[11] Física Educativa del IPN. Instrumentos de Investigación, in https://www.cicata.ipn.mx/oferta-educativa/fisicaeducativa/investigaci\%C3\%B3n/instrumentosinvestigaci\%C3\%B3n.html

[12] M. Olvera, L. Pérez-Trejo, A. Méndez-Sánchez \& M. Ramírez. Revista Iberoamericana para la Investigación y el Desarrollo Educativo, 9(7), (2018). 